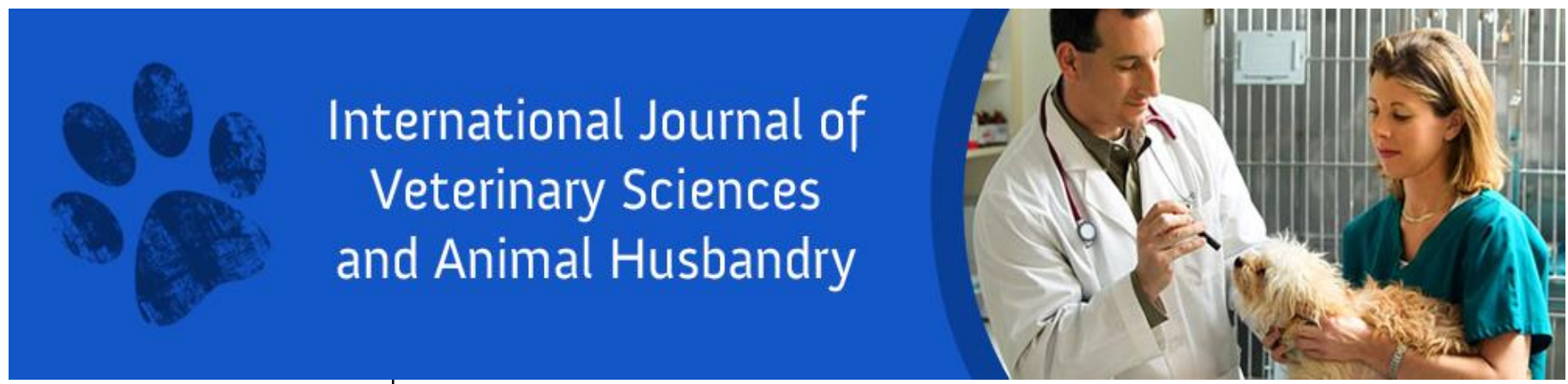

ISSN: $2456-2912$

VET 2021; 6(3): 04-08

(C) $2021 \mathrm{VET}$

www.veterinarypaper.com

Received: 04-03-2021

Accepted: 06-04-2021

Elly Tugiyanti

Poultry Production Lab, Faculty

of Animal Science, Jenderal

Soedirman University,

Purwokerto, Indonesia

Emmy Susanti

Animal Feed Ingredients Lab.

Faculty of Animal Science,

Jenderal Soedirman University,

Purwokerto, Indonesia

\section{Profile of digestive organ and carcass yield of broiler chickens reared with free-antibiotics feed-in different elevation area in Banyumas regency, Indonesia}

\author{
Elly Tugiyanti and Emmy Susanti
}

DOI: https://doi.org/10.22271/veterinary.2021.v6.i3a.350

\begin{abstract}
The research objective was to determine the digestive tract profile and carcass production of broiler chickens fed on antibiotic-free feed in areas with different elevation area. The study a survey designed according to the General Linear Model with purposive random sampling to choose farmer with 5.00010.000 chickens Cobb strain, used opened house and free-antibiotic feed. The data was analyzed used univariate one-way analysis of variance. The result showed that the different elevation area have not significantly affected ( $p>0.05)$ the crop, proventriculus, duodenum weight and lenght, inter villi space, carcass weight, carcass percentage of broiler chickens fed by antibiotic-free feed. However, it has significantly affected $(P<0.05)$ the weight of the final body, liver, small intestine, and it is positively considerably affected $(P<0.01)$ on gizzard weight and duodenum villi height. Antibiotic-free broiler chickens have kept in an opened house with different elevation area, hold on normally digestive organs and carcass production.
\end{abstract}

Keywords: antibiotic, duodenum, meat quality, villi, carcass production

\section{Introduction}

Since January 1, 2018, Indonesia's government, through the Ministry Regulation of Ministry of Agriculture No. 14/2017, has prohibited using antibiotics as a growth promotor (Antibiotic Growth Promotor/AGP) in livestock feed. Many farmers complained that the performance and immunity of the broilers were declining. Broiler chickens genetically perform fast growth and produce quality meat (Anggitasari et al., 2016) ${ }^{[5]}$. However, broiler chickens also have some drawbacks, such as low immunity against disease and prone to stress (Jannah et al., 2017) ${ }^{[10]}$. Body immune would decline faster when accompanied by stress (Adedokun et al., 2019) [1],

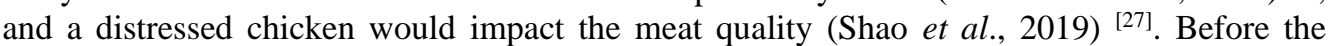
prohibition of antibiotics, almost all broiler breeders in Indonesia gave Antibiotics Growth Promoters (AGP) to the broilers through the feed.

The antibiotics activities reduce the microorganism population in the gastrointestinal tract, prevent disease, increase nutrient absorption, inhibit nutrient damage due to microorganisms, improve body growth, and improve feed efficiency (Kim et al., 2017) ${ }^{[13]}$. Antibiotics are directly reacting with the body's chicken immune system because antibiotics would fight the infectious agents that attack the chicken (Al-Khalaifah et al., 2018) ${ }^{[4]}$. A subtherapeutic dose of antibiotics could; however, given in the long run and ceased at the wrong time would produce antibiotics residual in the chicken carcass, meat, or visceral organs (Marlina et al., 2015; Masrianto et al., 2019) ${ }^{[16,17]}$ and bacterial resistance against antibiotics (Johnson et al., 2018) ${ }^{[11]}$. Antibiotics also have a side effect of reinforcing bone marrow activity that causes a disorder in red blood cell formation (Pilecky et al., 2019) ${ }^{[21]}$

Indonesia has a diverse range of temperature and humidity; the daylight temperature may exceed $34{ }^{\circ} \mathrm{C}$, and evening humidity could reach $93 \%$. The climate (temperature, humidity, precipitation, and interactions) significantly affect broiler chickens' performance (Nayak et al., $2015)^{[20]}$. The research located in the south of Central Java, Banyumas Regency, is the broiler chickens centre.
Corresponding Author: Elly Tugiyanti

Poultry Production Lab, Faculty of Animal Science, Jenderal

Soedirman University,

Purwokerto, Indonesia 
production of broiler chickens fed on antibiotic-free feed in areas with different elevation area. Our study objective was to determine the intestine organ profile, carcass

\section{Materials and Methods \\ Ethical approval}

The study was approved by the Indonesian Veterinary Association of Central Java II Branch, with certificate No. 02 / PDHI JT II / I / 2019 (January 7, 2019).

\section{Study Area}

This study was conducted at Banyumas Regency which have different elevation area and climatic condition (temperature, humidity, and precipitation) i.e. E1 ((Lower Elevation): $6 \mathrm{~m}$ above sea level (19.5-35.3 $\mathrm{C}, 90 \%, 425 \mathrm{~mm}^{3} /$ year $), \mathrm{E} 2$ (Medium Elevation): $55 \mathrm{~m}$ above sea level (20-29 $\mathrm{C}, 85 \%$, and $3.130 \mathrm{~mm}^{3} /$ year), and E3 (High Elevation): $200-1500 \mathrm{~m}$ above sea level $\left(22-29^{\circ} \mathrm{C}, 95 \%\right.$, and $3.585 \mathrm{~mm}^{3} /$ year $)$.

\section{Data Collection}

The study included a survey designed according to the General Linear Model (GLM) with purposive random sampling to select farmers with 5.000-10.000 chickens of Cobb strain, used opened the house and free-antibiotic feed. An accidental sampling technique has been used to determine the number of breeders in each area. Total broiler chickens aged 35-37 days old for observation was 27 heads per each area.

The observed variables were a) the profile of digestive organs including crop weight, liver weight, and intestinal weight, b) duodenum profile including duodenum weight and length and duodenal intervillous space, c) carcass production including slaughter weight, carcass weight, and carcass percentage.

\section{Analytical Procedure}

Twenty-seven broiler chickens aged 35-37 days were randomly selected from the respondents' in each area and rested in a litter cage for 4-6 hours before slaughter using the Kosher method. Data of crop, proventriculus, and gizzard were obtained by removing the content in these organs, then cleaning and draining the organs before they were. The liver weight data was measured by separating the liver from the bile pocket before weighing the liver. The weight of the intestinal was measured by cutting the intestines from the duodenum to ileum. Duodenum weight was measured by weighing the duodenum, while estimated duodenum length was by measuring the front end through the duodenum rear end. The height and duodenal intervillous space were measured by soaking intestine samples one by one into $70 \%$ alcohol for about 10 minutes. Then, the samples were put into xylitol and finally dipped into paraffin. The sample was thinly sliced using a microtome followed by a hematoxylin-eosin stain. A histology preparation was ready in a glass object for observation and measurement using a computer-aided microscope. The villi height, the item was determined first using an Olympus BX 51 microscope equipped with an Olympus DP 12 projector with 4-time magnification. The histology image appeared on the JVC TMH 1750C monitor screen. Then, all preparations image has captured a minimum of three times per slide of each parameter.

The slaughter weight data were the broilers' weight after being harvested and feed-fasted for 4 hours (drinking water was provided). The data was analyzed used univariate oneway analysis of variance.

\section{Results and Discussion Profile of Digestive Organ}

The digestive tract of chickens conveys food to the stomach, and this system comprises crop (elongation of the oesophagus located in the lower neck area), glandular stomach (proventriculus), muscular stomach (gizzard), and intestines. Profile the digestive organs of broiler chickens in three different elevation areas, as presented in Table 1.

Table 1: Profile the digestive organs of broiler chickens in three different areas

\begin{tabular}{|c|c|c|c|c|c|}
\hline Area & Crop weight $\left(g^{)}\right.$ns & Proventriculus weight $\left(\mathrm{gm}^{\text {) }}\right.$ ns & Gizzard weight $(\mathrm{g})^{\mathrm{hs}}$ & Liver weight $(\mathbf{g})^{\mathrm{s}}$ & Small intestines weight (g)s \\
\hline E1 & $5.96 \pm 0.41^{\mathrm{a}}$ & $4.94 \pm 0.02^{\mathrm{a}}$ & $25.61 \pm 2.88^{\mathrm{a}}$ & $34.40 \pm 4.93^{\mathrm{a}}$ & $26.22 \pm 1.10^{\mathrm{a}}$ \\
\hline E2 & $5.89 \pm 0.45^{\mathrm{a}}$ & $5.20 \pm 0.17^{\mathrm{a}}$ & $29.23 \pm 4.82^{b}$ & $36.81 \pm 2.86^{\mathrm{a}}$ & $30.67 \pm 2.61^{\mathrm{b}}$ \\
\hline E3 & $6.88 \pm 0.02^{\mathrm{a}}$ & $5.42 \pm 0.04^{\mathrm{a}}$ & $35.47 \pm 2.97^{\mathrm{c}}$ & $46.64 \pm 5.46^{\mathrm{b}}$ & $31.60 \pm 3.58^{\mathrm{b}}$ \\
\hline
\end{tabular}

${ }^{n s}$ The same superscripts within the column show no difference $(P>0.05)$

${ }^{\mathrm{s}}$ Different superscripts within column show a significant difference $(P<0.05)$

${ }^{\text {hs }}$ Different superscripts within column show a highly significant difference $(P<0.01)$

Analysis of variance result showed that the crops and proventriculus of broiler chickens that were kept under different elevation area showed no significant difference $(\mathrm{P}>0.05)$. It because the crop is the digestive organ to contain the digest temporarily. The proventriculus is the oesophagus hind part dilation, where secreted pepsinogen and $\mathrm{HCl}$ enzymes. Lierman et al. (2019) ${ }^{[15]}$. stated that the contributing factors to the size of proventriculus are the size and form of feed particles. Interestingly, the temperature in E1 is higher than that in E2 and E3, but the chicken's crop in E1 does not expand despite the increased intake of water. Tamzil (2014) ${ }^{[28]}$. stated that the chicken crop could enlarge due to excessive water intake. Chickens consume more water when the house temperature is higher. This study observed that the water intake of broiler chickens in E1 was the highest $(4,622.53 \pm 23.40 \mathrm{ml})$ than E2 $(4.340 \pm 47.88 \mathrm{ml})$ or E3 $(4,220 \pm 34.50 \mathrm{ml})$. This study did not observe a pendulous crop as reflected from the treatment broilers; therefore, the chickens could tolerate the amount of water intake.

The variance analysis showed that elevation area significantly affected gizzard weight $(P<0.01)$. The gizzard weight of broiler chickens in E3 was higher because the temperature, humidity, and precipitation in E3 were more appropriate than those in E1 and E2. Therefore, broiler chickens in E3 consumed the most feed of the three areas, i.e. 2.68 \pm 0.32 $\mathrm{g} /$ head (E3) vs $2.47 \pm 1.08 \mathrm{~g} /$ head (E1) and $2.49 \pm 1.05 \mathrm{~g} / \mathrm{head}$ (E2). According to Yosi et al. (2017) [31], broilers need an appropriate ambient temperature in a livable condition known as the thermoneutral zone. Aluwong et al. (2017) ${ }^{[3]}$. Stated that broiler chickens' thermoneutral area is $18^{\circ} \mathrm{C}$ to $24^{\circ} \mathrm{C}$. However, Candido et al. (2016) ${ }^{[34]}$ argued that the convenient temperature and humidity for broiler chickens varied on the first week $\left(33.0 \pm 0.5^{\circ} \mathrm{C}\right.$ and $\left.64.8 \pm 5.3 \%\right)$, second week $\left(30.0 \pm 0.3^{\circ} \mathrm{C}\right.$ and $\left.60.3 \pm 5.7 \%\right)$, and the third week $\left(27.0 \pm 0.3^{\circ} \mathrm{C}\right.$ and 59.6 $\pm 4.8 \%)$. Temperature and humidity that are approaching the thermoneutral zone resemble the climate in 
E3. High feed intake would make the gizzard work harder to grind the feed into smaller particles; consequently, the gizzard muscle gets enlargement. The temperature in E1, especially during daylight, is very high, and low precipitation; because of nearby the sea. According to Mutibvu et al. (2017) ${ }^{[19]}$, broiler chickens consumed more waters to maintain body temperature. High water consumption would cause low feed intake and relieve gizzard work.

The liver weights of broiler chickens (Table 1) across regencies in this study were within the normal range, which was in line with Kokoszyński et al. (2017) ${ }^{[14]}$ reporting 42.5$49.9 \mathrm{~g}$. The analysis of variance result showed that different elevation area significantly affected $(P<0.05)$ liver weight because the liver performance is related to the amount of feed consumed; the more feed consumed, the harder the liver works, hence affecting the liver weight (Zaefarian et al., 2019)] [32]. This organ can quickly adapt to a change in feed and the environment. The contributing factors to liver weight include the type and amount of feed consumed (Kokoszyński et al., 2017) ${ }^{[14]}$.

The small intestine is a vital organ responsible for the digestion and absorption of nutrients from the diet. Analysis of variance showed that broiler farming locations with different elevation area significantly affected $(P<0.05)$ the small intestines weight. It was because the broiler chickens kept in different elevation area exhibited diverse growth and body weight. This finding was supported by Kokoszyński et al. (2017) ${ }^{[14]}$ and Purwinarto et al. (2020) ${ }^{[23]}$ that for broiler chickens to have a fast and efficient growth as well as optimum final body weight, and it takes optimum intestinal performance (duodenum, jejunum, and ileum) as well as nerve system and circulation. This study found that the highest body weight obtained from broiler chickens kept in E3 $(1.70 \pm 0.71 \mathrm{~kg})$, followed by that in E2and E1, i.e., $1.75 \pm 0.27 \mathrm{~kg}$ and $1.68 \pm 0.77 \mathrm{~kg}$, respectively.

\section{Duodenum Profile}

Table 2: Duodenum profile of broiler chickens in three different areas

\begin{tabular}{|c|c|c|c|c|}
\hline Area & Duodenum length $(\mathrm{cm})^{\mathrm{ns}}$ & ${\text { Duodenum weight }(\mathrm{gm})^{\mathrm{ns}}}$ & Duodenum villi height $(\mu \mathrm{m})^{\mathrm{hs}}$ & ${\text { Inter villous space } \mu \mathrm{m})^{\mathrm{ns}}}$ \\
\hline E1 & $34.22 \pm 3.62^{\mathrm{a}}$ & $6.39 \pm 0.20^{\mathrm{a}}$ & $1185.57 \pm 37.22^{\mathrm{a}}$ & $2.55 \pm 0.03$ \\
\hline E2 & $33.99 \pm 2.54^{\mathrm{a}}$ & $6.52 \pm 0.63^{\mathrm{a}}$ & $1498.54 \pm 26.36^{\mathrm{b}}$ & $3.29 \pm 0.14$ \\
\hline E3 & $34.87 \pm 3.91^{\mathrm{a}}$ & $6.84 \pm 0.24^{\mathrm{a}}$ & $1609.11 \pm 17.34^{\mathrm{c}}$ & $4.27 \pm 0.86$ \\
\hline
\end{tabular}

ns the same superscripts within column show no difference $(\mathrm{P}>0.05)$

${ }^{\mathrm{s}}$ different superscripts within the column show a significant difference $(P<0.05)$.

Duodenum is the longest part of the small intestines, and it functions in the digestion process and nutrient feed absorption. Feed and nutrient digestibility affected by duodenum size, villi heights, and duodenal intervillous space. Duodenum profile of broiler chickens in three different areas, as presented in Table 2. Sari et al. (2016) ${ }^{[25]}$ and Satimah et al. (2019) ${ }^{[26]}$ reported that the duodenum weight of broiler chickens was $4.648 \mathrm{~g}(0.7 \%$ of body weight $664.00 \mathrm{~g})$ and the length was $31.00-35.00 \mathrm{~cm}$. Analysis of variance result demonstrated that farming location at different elevation area did not significantly affect $(\mathrm{P}>0.05)$ duodenum weight and length of broiler chickens because the nutrient content in feed offered from the starter to harvest period was equal. According to Satimah et al. (2019) ${ }^{[26]}$ and Wang et al. (2016) ${ }^{[30]}$, the duodenum's weight and length were near related to the length and duodenal intervillous space, digestion process, and nutrient absorption.

Villi is the mucus membrane's projection into the small intestine lumen that extends the surface area to absorb nutrition. There are longer and more villi in the duodenum than in ileum (Prakatur et al., 2019) ${ }^{[22] . ~ Q u ~ e t ~ a l . ~(2019) ~}{ }^{[24]}$ stated that antibiotics affected the height of duodenum villi. After the prohibition of antibiotics for animal feed, the height of the duodenum villi of broilers in this study (Table 2) was

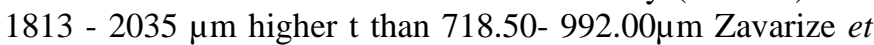
al. (2012) ${ }^{[33]}$ research. This finding showed that antibioticfree feed improved total duodenum villi. The duodenal intervillous space in this finding was by Budiartawan et al. (2018) ${ }^{[8]}$, i.e., $3.82 \pm 1.07-4.01 \pm 1.17 \mu \mathrm{m}$. The variance analysis showed that areas and climate did not significantly affect $(P>0.05)$ height and duodenal intervillous space. Inter villous space is significantly affected by the chicken ageing, whereas the age of chickens in this study was relatively similar.

The histology of duodenum villi of broiler chickens aged 3537 days in three different elevation area shown in Figure 1. Duodenum is small intestines with four layers, i.e., mucosa, submucosa, tunica muscular, and tunica serosa. Villi is the projection and distinctive feature of mucosa that absorbs nutrition, vitamin, and mineral and protects against pathogenic bacteria (Alshamy et al., 2018) ${ }^{[2]}$.
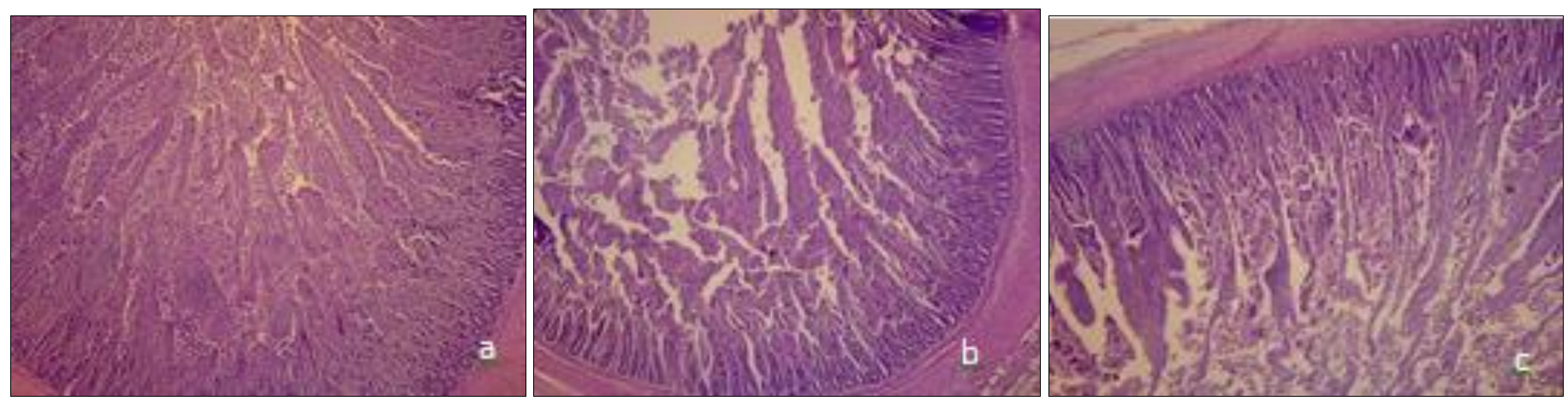

Fig 1: Histology of duodenum villi of broiler chickens kept in Lower elevation (a), Medium elevation (b) and High elevation (c) 


\section{Carcass yields}

Table 3: Carcass yield

\begin{tabular}{|c|c|c|c|}
\hline Area & $\begin{array}{c}\text { Slaughter weight } \\
(\mathbf{g})^{\mathbf{s}}\end{array}$ & $\begin{array}{c}\text { Carcass weight } \\
(\mathbf{g})^{\mathbf{n s}}\end{array}$ & $\begin{array}{c}\text { Carcass percentage } \\
(\mathbf{\%})^{\mathbf{n s}}\end{array}$ \\
\hline E1 & $1,608.00 \pm 149.23^{\mathrm{a}}$ & $1,002.00 \pm 60.25$ & $62.40 \pm 2.433$ \\
\hline E2 & $1,614.00 \pm 19.49^{\mathrm{ab}}$ & $1,064.00 \pm 129.15$ & $65.91 \pm 5.52$ \\
\hline E3 & $2,036.00 \pm 571.52^{\mathrm{b}}$ & $1,366.00 \pm 100.40$ & $67.03 \pm 1.217$ \\
\hline
\end{tabular}

ns the same superscripts within columns show no difference $(P>0.05)$ ${ }^{s}$ different superscripts within column show a significant difference $(P<0.05)$

Table 3 showed that slaughter weight and carcass percentage of broiler chickens aged 35-37 days in this research were relatively similar to broilers fed with antibiotics were around 1,746 $\pm 36.5 \mathrm{~g}$ (Miles et al., 2006) ${ }^{[18]}$ and $66.4 \%$ (Tayeri et al.,2018) ${ }^{[29]}$. It showed that the bodyweight of all chickens across the three different elevation area was stable despite the absence of antibiotics in the feed. Jumiati et al. (2017) [12] reported relatively similar slaughter weight with this study $(1,707.13 \pm 59.28-1,867.25 \pm 83.91 \mathrm{~g})$. The analysis of variance showed that the farming location significantly affected $(P<0.05)$ slaughter weight, did not significantly affect $(\mathrm{P}>0.05)$ on carcass weight and carcass percentage. The slaughter weight of broiler chickens was different elevation areas due to different temperatures, humidity, and precipitation, which the chickens' welfare. According to Baracho et al. (2018) ${ }^{[6]}$ and Baracho et al. (2019) ${ }^{[7]}$, broiler welfare's contributing factors include temperature, humidity, and livestock. High environmental temperature is one of the challenges to the optimum performance of broiler chickens. Dharmawan et al. (2016) ${ }^{[9]}$ stated that broiler chickens would experience high-temperature stress, causing a decrease in feed intake and slaughter weight.

\section{Conclusion}

\section{The conclusion of this survey research was}

1. Antibiotic-free broiler chickens have kept in an opened house with different elevation area, hold on normally digestive organs and carcass production. The crop, proventriculus, and liver's weight of chickens' broiler the same relatively. So, it is with the height of duodenum, and intervillous space.

2. A different elevation area produced slaughter weight, villi height, gizzard weight, and small intestine weight of broiler chicken differently

\section{Acknowledgement}

The authors express their attitude to the University of Jenderal Soedirman for funding the research through Superior Research Grant UNSOED year 2019.

\section{References}

1. Adedokun SA, Olojede OC. Optimizing gastrointestinal integrity in poultry: The role of nutrients and feed additives. Front. Vet. Sci 2019;5:348. https://doi.org/10.3389/fvets.2018.00348

2. Alshamy Z, Richardson KC, Hünigen H, Hafez HM, Plendl J. Comparison of the gastrointestinal tract of a dual-purpose to a broiler chicken line: A qualitative and quantitative macroscopic and microscopic study. PLOS ONE 2018;13(10):e0204921. https://doi.org/10.1371/journal.pone.0204921;

3. Aluwong T, Sumanu VO, Ayo JO, Ocheja BO, Zakari FO, Minka NS. Daily rhythms of cloacal temperature in broiler chickens of different age groups administered with zinc gluconate and probiotic during the hot-dry season. Physiol Rep 2017; 5(12):e13314. DOI:10.14814/phy2.13314;

4. Al-Khalaifah HS. Benefits of probiotics and/or prebiotics for antibiotic-reduced poultry. Poult. Sci 2018;97(11):3807-3815. https://doi.org/10.3382/ps/pey160;

5. Anggitasari S, Sjofjan O, Irfan DIH. Effect of some kinds of commercial feed on quantitative and qualitative production performance of broiler chicken. Buletin Peternakan 2016;40(3):187-196.

https://doi.org/10.21059/buletinpeternak.v40i3.11622;

6. Baracho MS, Nääs IA, Betin PS, Moura DJ. Factors that Influence the Production, Environment, and Welfare of Broiler Chicken: A Systematic Review. Braz. J. Poultry Sci 2018;20(3):617-624. https://doi.org/10.1590/18069061-2018-0688;

7. Baracho MS, Nääs IA, Lima NDS, Cordeiro AFS, Moura DJ. Factors Affecting Broiler Production: A MetaAnalysis. Braz. J Poultry Sci 2019;21(3):eRBCA--1052. https://dx.doi.org/10.1590/1806-9061-2019-1052;

8. Budiartawan Alit IK, Darmawan IGAC, Berata IK, Setiasih NLE. Perkembangan secara histologi vili duodenum ayam pedaging yang diberikan imbuhan asam butirat pada pakan. Indonesia Medicus Veterinus 2018, 522-530. https://doi.org/10.19087/imv.2018.7.5.522;

9. Dharmawan R, Prayogi HS, Nurgiartiningsih VMA. Penampilan produksi ayam pedaging yang dipelihara pada lantai atas and lantai bawah. Jurnal Ilmu-Ilmu Peternakan 2016;26(3):27-37. https://doi.org/10.21776/ub.jiip.2016.026.;

10. Jannah PN, Sugiharto, Isroli. The effect of boiled turmeric water on the number of leukocyte and differentiation leukocyte of broilers. Jurnal Ternak Tropika 2017;18(1):15-19.

https://doi.org/10.21776/ub.jtapro.2017.018.1.3;

11. Johnson TJ, Bonnie P. Youmans BP, Noll S, Cardona C, Evans NP et al. A consistent and predictable commercial broiler chicken bacterial microbiota in antibiotic-free production displays strong correlations with performance. Applied and Environmental Microbiology 2018;84(12):118. https://doi.org/10.1128/AEM.00362-18;

12. Jumiati S, Nuraini, Aka R. Slaughter weight, carcass, giblet dan abdominal fat broiler chickens are given Curcumaxanthorrhiza, roxb in the feed. Jitro 2017;4(3):19. http://Dx.Doi.Org/10.33772/Jitro.v4i3;

13. Kim S, Covington A, Pamer EG. The intestinal microbiota: Antibiotics, colonization resistance. Immunol Rev 2017;279(1):90-105. https://10.1111/imr.12563

14. Kokoszyński D, Bernacki Z, Saleh M, Stęczny K, Binkowska M. Body conformation and internal organs characteristics of different commercial broiler lines. Braz. J Poultry Sci 2017;19(1):047-052. https://doi.org/10.1590/1806-9061-2016-0262;

15. Liermann W, Bochnia M, Berk A, Böschen V, Hüther L, Zeyner, and Dänicke S. Effects of feed particle size and hydro-thermal processing methods on starch modification, nutrient digestibility, and the performance and the gastrointestinal tract of broilers. Animals (Basel) 2019;9(6):294. https://doi.org/10.3390/ani9060294

16. Marlina AN, Zubaidah E, Sutrisno A. Pengaruh pemberian antibiotika saat budidaya terhadap keberadaan residu pada daging and hati ayam pedaging dari peternakan rakyat. Jurnal Ilmu-Ilmu Peternakan 
2015;25(2):10-19.

https://doi.org/10.21776/ub.jiip.2015.025.02.02;

17. Masrianto, Arief II, Taufik E. Antibiotic Residue Analysis of Chicken Meat and Liver in Pidie Jaya, Aceh Province. Jurnal Ilmu Produksi and Teknologi Hasil Peternakan 2019;07(3):102-110. https://doi.org/10.29244/jipthp.7.2.102-110;

18. Miles RD, Butcher GD, Henry PR, Littell RC. Effect of antibiotic growth promoters on broiler performance, intestinal growth parameters, and quantitative morphology. J Poult. Sci 2006;85:476-485. DOI:10.1093/ps/85.3.476;

19. Mutibvu T, Chimonyo M, Halimani TE. Physiological responses of slow-growing chickens under diurnally cycling temperature in a hot environment. Braz. J. Poultry Sci 2017;19(4):567-576. https://doi.org/10.1590/1806-9061-2017-0485;

20. Nayak GD, Behura NC, Sardar KK, Mishra PK. Effect of climatic variables on production and reproduction traits of coloured broiler breeder poultry. Vet. World 2015;8(4):472-477. DOI: 10.14202/vetworld.2015.472477

21. Pilecky M, Schildberger A, Knabl L Orth-Holler D, Weber V. Influence of antibiotic treatment on the detection of $S$. aureus in whole blood following pathogen enrichment. BMC Microbiol 2019;19:180. https://doi.org/10.1186/s12866-019-1559-7.

22. Prakatur I, Miskulin M, Pavic M, Marjanovic K, Blazicevic V, Ivan Miskulin I et al. Intestinal morphology in broiler chickens supplemented with propolis and bee pollen. Animals 2019;9(301):1-12. https://doi.org/10.3390/ani9060301;

23. Purwinarto, Suprijatna E, Kismiati S. Effect of addition of cassava peel and lactic acid bacteria as feed additives on the digestive profile of broiler chicken. JPI 2020;22(1):101-109. DOI: $10.25077 /$ jpi.22.1.101109.2020;

24. Qu H, Cheng Y, Chen Y, Li J, Zhao Y, Zhou Y. Effects of dietary zeolite supplementation as an antibiotic alternative on growth performance, intestinal integrity, and cecal antibiotic resistance genes abundances of broilers. Animals (Basel) 2019;9(11):909. DOI: 10.3390/ani9110909;

25. Sari, Hafid H, Tasse AM. Kajian produksi carcass dan non carcass ayam kampung dengan pemberian ransum komersial tersubstitusi tepung kulit biji kedelai. JITRO 2016;3(3):67-80. http://dx.doi.org/10.33772/jitro.v3i3.2571;

26. Satimah S, Yunianto VD, Wahyono F. Relative weight and small intestine length given feed composed of microparticle eggshell with supplemental probiotic Lactobacillus sp. Jurnal Sains Peternakan Indonesia 2019;14(4):396-403. https://doi.org/10.31186/jspi.id.14.4.396-403;

27. Shao D, Wang Q, Hu Y, Shi S, Tong H. Effects of cyclic heat stress on the phenotypic response, meat quality and muscle glycolysis of breasts and thighs of yellow-feather broilers, Italian J Anim. Sci 2019;18(1):301-308. https://doi.org/10.1080/1828051X.2018.1520051;

28. Tamzil MH. Stres panas pada unggas: Metabolisme, akibat dan upaya penanggulangannya. Wartazoa 2014;24(2):57-66.

DOI: http://dx.doi.org/10.14334/wartazoa.v24i2.1049;

29. Tayeri V, Seidavi A, Asadpour L, Phillips CJC. A comparison of the effects of antibiotics, probiotics, synbiotics, and prebiotics on the performance and carcass characteristics of broilers. Vet. Res. Commun 2018;42(3):195-207. DOI: 10.1007/s11259-018-9724-2;

30. Wang X, Farnell Y Z, Peebles ED, Kiess AS, Wamsley KGS, Zhai W. Effects of prebiotics, probiotics, and their combination on growth performance, small intestine morphology, and resident Lactobacillus of male broilers. Poultry Sci 2016;95:1332-1340. https://doi.org/10.3382/ps/pew030;

31. Yosi F, Widjastuti T, Setiyatwan H. Performance and physiological responses of broiler chickens supplemented with potassium chloride in drinking water under environmental heat stress. Asian J Poult. Sci 2017;11:3137. https://doi.org/10.3923/ajpsaj.2017.31.37;

32. Zaefarian F, Abdollahi MR, Cowieson A, Ravindran V. Avian Liver: The Forgotten Organ. Animals 2019; 9 (2): 63 DOI: 10.3390/ani9020063;

33. Zavarize KC, Sartori J, Elisabeth G, Antonio P. Morphological changes of the intestinal mucosa of broilers and layers as affected by fasting before sample collection. Rev. Bras. Ciênc. Aví 2012;14:21-25. DOI:10.1590/S1516-635X2012000100004;

34. Cândido MGL, Tinoco IDFF, Pinto FDD, Santos NT, Roberti RP. Determination of thermal comfort zone for early-stage broilers. Engenharia Agrícola 2016;36(5):760-767. https://dx.doi.org/10.1590/18094430-Eng.Agric.v36n5p760-767/2016. 